\title{
PENGETAHUAN SISWA SMK NEGERI 1 PERCUT SEI TUAN TENTANG PENCEGAHAN PENYEBARAN COVID-19 DENGAN METODE $5 \mathrm{M}$
}

\author{
Devi Novita Damanik ${ }^{1}$, Mona Hastuti \\ 1,2Program Diploma III Keperawatan/AKPER Malahayati Medan/Indonesia) \\ Email: friendly_devi57@gmail.com,monahastuti77@gmail.com
}

\begin{abstract}
In dealing with the Covid-19 pandemic, it is necessary to have the participation of the community in synergy with the government, so that it can break the chain of the spread of Covid-19. The country's success in dealing with the Covid-19 outbreak cannot be separated from the community's compliance with the rules and policies made by the government, one of which is by applying the $5 M$ method as an effort to prevent the spread of COVID-19. This research was aimed To know the level of knowledge of SMKN 1 PST students about preventing the spread of the Corona Virus with 5M. This research is a quantitative study using a quantitative descriptive research design using univariate data analysis. Univariate analysis to describe descriptively the frequency distribution of respondents' demographic data consisting of: gender, age, class. The knowledge level variable will describe the amount and level of knowledge with a level presentation. The results showed that the average age of the respondents was at the age of 17 years, namely 52 people (53.11\%). The gender of the majority of the respondents was 50 men (52.08\%). And each response is in the same class average between class X, XI and XII, namely $34.33 \%, 33.33 \%$ and $32.39 \%$. Presentation of knowledge level: good knowledge 40 people (41.67\%), sufficient knowledge 36 people (37.50\%) and less knowledge 20 people $(20.83 \%)$. The results of this study indicate that there are students who have less knowledge as much as $20.83 \%$.
\end{abstract}

Keywords: Corona virus disease, knowledge, preventing the spread of the corona virus.

\section{PENDAHULUAN}

Kementerian Kesehatan RI menyebutkan bahwa awal tahun 2020, masyarakat dunia dikagetkan dengan kemunculan penyakit Coronavirus Disease 2019 (Covid-19). Pada tanggal 30 Januari 2020 WHO menetapkan Covid-19 sebagai kedaruratan kesehatan masyarakat yang meresahkan dunia. Penambahan jumlah kasus Covid-19 berlangsung cukup cepat dan sudah terjadi penyebaran antar negara. Total kasus terkonfirmasi Covid-19 di dunia mencapai 4.248.389 kasus dan kasus kematian berjumlah 294.046 (CFR 6,9\%) di 215 negara yang terjangkit (Kemenkes RI, 2020). Tanda dan gejala COVID-19 bervariasi salah satunya adalah Infeksi Saluran Pernapasan Akut (ISPA) meskipun pada pemeriksaan radiologi foto thorax, hasilnya tidak menunjukkan tanda-tanda khas pneumonia (Guan et. al, 2020).

Kemenkes menjelaskan manifestasi klinis dari infeksi COVID-19, diantaranya demam, batuk, pilek, 
gangguan saluran pernapasan, dan sakit tenggorokan (Kemenkes RI, 2020). Masih ada masyarakat Indonesia yang tidak menghiraukan himbauan pemerintah, padahal pada kenyataannya itu adalah kesalahan. Masyarakat merasa dapat menjaga diri dengan baik sekalipun berada di luar rumah atau di tengah keramaian, sehingga masyarakat merasa pintar atas dasar persepsi mereka sendiri (Anies, 2020). Hal ini terjadi disebabkan masih rendahnya kemampuan literasi masyarakat maupun masih banyak masyarakat yang tidak memiliki akses pada media-media informasi, sehingga pengetahuan yang dimiliki oleh masyarakat masih minim merebaknya wabah Covid-19 ini (Buana, 2020).

Dalam menghadapi pandemi Covid19 diperlukan peran serta dari masyarakat yang bersinergi dengan pemerintah, sehingga dapat memutus rantai penyebaran Covid-19. Sikap masyarakat dalam merespon setiap kebijakan pemerintah dalam memutus rantai penyebaran dan penularan Covid19 juga sangatlah penting. Beberapa negara yang dianggap gagal dalam menghadapi wabah Covid-19 seperti Italia dan India diakibatkan sikap masyarakat yang kurang baik dalam merespon kebijakan pemerintah untuk memutus penyebaran Covid-19. Sedangkan negara yang dianggap berhasil dalam menghadapi wabah
Covid-19 seperti Cina, Vietnam, Jepang dan Korea Selatan. Keberhasilan negara tersebut dalam menghadapi wabah Covid-19 tidak terlepas dari pemantauan serta pengawasan yang dilakukan oleh pemerintah yang didukung oleh kepatuhan masyarakat terhadap aturan dan kebijakan yang dibuat oleh pemerintah (Cahyadi, 2020).

Covid-19 dapat dicegah dengan penerapan dan pengetahuan mengenai 5M sebagai upaya penyebaran covid-19. Gerakan 5M yang dimaksud adalah memakai masker, mencuci tangan pakai sabun dan air mengalir, menjaga jarak, menjauhi kerumunan, mengurangi mobilitas dan interaksi. Karena kita tidak kuasa menghentikan Virus Corona, maka yang dapat kita lakukan adalah mencegahnya menyebar lebih luas (Mona, 2020). Terkait tentang pengetahuan dan informasi yang didapat oleh masyarakat mengenai cara pemutusan rantai penyebaran virus Covid-19 beberapa penelitian yang terkait sebagai berikut: Pengetahuan Mahasiswa kesehatan tentang pencegahan Covid-19 di Indonesia tergolong baik menurut penelitian yang dilakukan oleh (Sukesih, et. al., 2020). Pengetahuan masyarakat di Pekalongan tentang Covid 19 dan penanganannya menyebutkan bahwa $72 \%$ pengetahuan masyarakat baik namun masih ada $77 \%$ masyarakat yang mengharapkan 
informasi mengenai Covid-19 dan pencegahannya (Nidaa, 2020). Pengetahuan siswa mengenai pencegahan penularan Covid-19 rendah (Erlyn, et al., 2020).

Pentingnya siswa sekolah sebagai salah satu yang berperan dalam memutus mata rantai penyebaran Covid19 maka dengan ini peneliti tertarik untuk mengetahui bagaimana tingkat pengetahuan masyarakat khususnya siswa sekolah menengah atas mengenai upaya pencegahan penyebaran Covid 19 dengan metode $5 \mathrm{M}$.

\section{METODE}

Penelitian ini merupakan penelitian kuantitatif dengan menggunakan rancangan penelitian deskriptif kuantitatif dengan desain penelitian crossectional. Penelitian dilaksanakan selama 1 bulan yaitu bulan oktober 2020. Penelitian ini merupakan penelitian yang bertujuan menjelaskan fenomena yang ada dengan menggunakan angka-angka untuk menjelaskan karakteristik individu atau kelompok (Syamsudin \& Damaianti, 2018). Penelitian ini menilai sifat dari kondisi-kondisi yang tampak. Tujuan dalam penelitian ini dibatasi untuk menggambarkan pengetahuan Siswa/I SMKN 1 Percut Sei Tuan mengenai pencegahan penyebaran virus corona dengan metode $5 \mathrm{M}$.
Penelitian ini bertempat di SMKN 1 Percut Sei Tuan sebagai salah satu sekolah Menengah Kejuruan yang memiliki banyak siswa di kota Medan. Lokasi penelitian dianggap bisa mewakili masyarakat dengan tahapan usia remaja.

Populasi dalam penelitian ini adalah seluruh siswa kelas 1, 2 dan 3 SMKN 1 Percut Sei Tuan yang berjumlah 2475 orang. Teknik pengambilan sampel pada penelitian ini dilakukan dengan menggunakan teknik simple random sampling. Besar sampel yang ditentukan dengan rumus Slovin menurut Notoadmodjo (2010) sebagai berikut:

$$
\begin{aligned}
& n=\frac{N}{1+N e^{2}} \\
& \mathrm{n}=2475 / 1+2475(0,1) 2=96,11=96 \\
& \text { orang }
\end{aligned}
$$

Keterangan :

$\mathrm{n}=$ Besar sampel

$\mathrm{N}=$ Jumlah Populasi $(\mathrm{N}=2475)$

$\mathrm{e}=$ Tingkat kepercayaan $(10 \%)$

Maka berdasarkan perhitungan rumus di atas, pada penelitian ini jumlah sampel yang digunakan ada sebanyak 96 orang.

Instrumen yang digunakan dalam penelitian ini adalah: Instrumen data demografi sampel dan Instrumen Tingkat Pengetahuan Responden Mengenai Pencegahan Penyebaran Virus Covid 19 yang telah dilakukan uji validitas dengan nilai $\mathrm{r}$ tabel 0,361 dengan sig. 5\% dan uji realibilitasnya 
mendapatkan koefisien realibilitas alfa 0.7. Dalam masa pandemi ini penelitian dilakukan secara daring dengan menggunakan media menyebar kuesioner melalui pesan Whatssapp dan melakukan pertemuan dengan media Google Meeting. Penelitian diawali dengan pengumpulan data/survey awal yang dilakukan oleh peneliti, penelitian dilanjutkan dengan pengisian lembar persetujuan menjadi sampel oleh calon responden dan dilakukan dengan membagikan pengisian kuesioner secara daring dengan media Google Form, kemudian peneliti mengumpulkan sampel melalui grup WA dan akan dilakukan pembagian lembar isian biodata sampel melalui media Google form, penelitian dilanjutkan dengan membagikan kuesioner penelitian dengan menggunakan Google form.

Penelitian ini menggunakan analisa data univariat. Pada analisa univariat dilakukan untuk menjabarkan secara deskriptif untuk menghitung distribusi frekuensi data demografi responden yang terdiri dari: jenis kelamin, usia, kelas. Kemudian untuk variable tingkat pengetahuan maka akan dideskripsikan jumlah dan tingkatan pengetahuannya dengan presentasi tingkatan.

HASIL DAN PEMBAHASAN

Karakteristik Demografi Responden
Karateristik responden meliputi usia, jenis kelamin, dan kelas yang dapat dilihat pada Tabel 1 dibawah ini:

Tabel 1. Karakteristik responden

\begin{tabular}{|c|c|c|c|}
\hline No & $\begin{array}{c}\text { Karakteristik } \\
\text { Responden }\end{array}$ & n & $\%$ \\
\hline \multicolumn{4}{|c|}{ Usia } \\
\hline 1. & 15 tahun & 13 & 13.54 \\
\hline 2. & 16 tahun & 25 & 26.04 \\
\hline 3. & 17 tahun & 52 & 53.11 \\
\hline \multirow[t]{2}{*}{4.} & 18 tahun & 7 & 7.29 \\
\hline & Jumlah & 96 & 100 \\
\hline \multicolumn{4}{|c|}{ Jenis Kelamin } \\
\hline 1. & Laki-laki & 50 & 52.08 \\
\hline \multirow[t]{2}{*}{2.} & Perempuan & 46 & 47.92 \\
\hline & Jumlah & 96 & 100 \\
\hline \multicolumn{4}{|c|}{ Kelas } \\
\hline 1. & $X$ & 33 & 34.38 \\
\hline 2. & XI & 32 & 33.33 \\
\hline \multirow[t]{2}{*}{3.} & XII & 31 & 32.29 \\
\hline & Jumlah & 96 & 100 \\
\hline
\end{tabular}

Berdasarkan Tabel 1 tersebut menunjukkan mayoritas usia responden adalah di usia 17 tahun yaitu sebanyak 52 orang $(53.11 \%)$ dan terendah di usia 18 tahun sejumlah 7 orang (7.29\%). Jenis kelamin responden mayoritas laki-laki sebanyak 50 orang (52.08\%). Dan masing-masing respon berada pada rerata kelas yang sama antara kelas X, XI dan XII yaitu $34.33 \%$, 33.33\% dan 32.39\%.

Berdasarkan dari data 96 responden didapatkan bahwa mayoritas responden berada di usia 17 tahun. Soekanto (2019) menyatakan bahwa faktor yang mempengaruhi tingkat pengetahuan seseorang adalah: tingkat pendidikan, informasi yang diterima, budaya dan tingkah laku serta 
pengalaman. Hal ini sejalan dengan karakteristik demografi yang ditunjukkan oleh responden di usia 17 tahun dan di tingkat pendidikan sekolah menengah merupakan usia yang matang dalam menerima informasi/ pengetahuan. Pendidikan adalah upaya untuk memberikan pengetahuan sehingga siswa mampu memiliki tingkat pengetahuan yang baik, Seseorang yang mempunyai sumber informasi yang lebih banyak akan mempunyai pengetahuan lebih luas, serta sesuatu yang pernah dialami seseorang akan menambah pengetahuan tentang sesuatu yang bersifat informal (Soekanto, 2019).

Pengetahuan Responden

Tabel 2. Distribusi Frekuensi Data Pengetahuan

\begin{tabular}{llcc}
\hline No & $\begin{array}{c}\text { Tingkat } \\
\text { Pengetahuan }\end{array}$ & n & \% \\
\hline 1 & Pengetahuan Baik & 40 & 41,7 \\
2 & Pengetahuan Cukup & 36 & 37,5 \\
3 & $\begin{array}{l}\text { Pengetahuan } \\
\text { Kurang }\end{array}$ & 20 & 20,8 \\
\hline & Jumlah & $\mathbf{9 6}$ & $\mathbf{1 0 0}$ \\
\hline
\end{tabular}

Berdasarkan Tabel 2 menunjukkan bahwa presentasi masing-masing tingkatan pengetahuan adalah pengetahuan baik sebanyak 40 orang (41.67\%), pengetahuan cukup sebanyak 36 orang $(37.50 \%)$ dan pengetahuan kurang sebanyak 20 orang (20.83\%) dan mayoritas responden menjawab salah di poin pertanyaan no 13 s.d 20 pada metode mencegah kerumunan dan mengurangi mobilitas. Dari hasil penelitian tersebut menunjukkan bahwa komunitas siswa sekolah yang mewakili menunjukkan angka pengetahuan yang baik sebesar $41.67 \%$. Sebagian besar siswa sudah memahami bagaimana metode 5M mampu mencegah penyebaran Covid 19 hal ini sejalan dengan hasil penelitian yang disampaikan oleh Sukesih et al., (2020) bahwa mewakili mahasiswa, pengetahuan mahasiswa kesehatan tentang pencegahan Covid-19 di Indonesia tergolong baik. Tingkat pengetahuan siswa SMKN 1 Percut Sei Tuan yang baik berdasarkan hasil pengetahuan juga sejalan dengan yang ditunjukkan oleh penelitian yang dilakukan Nidaa (2020) mengenai pengetahuan masyarakat di Pekalongan tentang Covid 19 dan penanganannya menyebutkan bahwa $72 \%$ pengetahuan masyarakat baik namun masih ada $77 \%$ masyarakat yang mengharapkan informasi mengenai Covid-19 dan pencegahannya. Namun hasil penelitian ini tidak sejalan dengan hail penelitian Erlyn et al., (2020) yang menunjukkan pengetahuan siswa mengenai pencegahan penularan Covid-19 rendah.

Namun, dari hasil penelitian ini masih terdapat siswa yang memiliki pengetahuan yang kurang sebanyak $20,83 \%$. Hal inilah yang menyebabkan 
penyebaran virus Covid 19 masih memiliki angka yang tinggi sesuai dengan pernyataan Kemenkes RI (2020) bahwa tidak tertibnya perilaku masyarakat membuat angka kasus COVID-19 di Indonesia tetap melonjak drastis setiap harinya (Kemenkes RI, 2020). Dan sejalan dengan pernyataan Power (2020) bahwa kelompok yang paling berisiko dan pengetahuannya tentang COVID-19 masih rendah adalah kelompok anak-anak.

\section{KESIMPULAN DAN SARAN}

\section{Kesimpulan}

Berdasarkan hasil penelitian yang dilakukan SMKN 1 Percut Sei Tuan mayoritas berusia 17 tahun dan memiliki pengetahuan yang baik mengenai pencegahan penyebaran virus Covid-19 dengan Metode 5M yang dibuktikan dengan mayoritas pengetahuan siswa baik sebanyak 40 orang (41.67\%), pengetahuan cukup sebanyak 36 orang $(37.50 \%)$ dan pengetahuan kurang sebanyak 20 orang (20.83\%). Namun dari hasil penelitian ini masih terdapat siswa yang memiliki pengetahuan yang kurang sebanyak 20,83\%. Sehingga penelitian selanjutnya harus memikirkan cara yang tepat untuk meningkatkan pengetahuan masyarakat khususnya siswa di sekolah mengenai Corona Virus 19 umumnya dan khususnya mengenai pencegahan penyebarannya dengan metode 5M.

\section{Saran}

Berdasarkan hasil di atas diharapkan pada penelitian selanjutnya, peneliti dapat memikirkan cara atau solusi untuk meningkatkan pengetahuan siswa yang masih cukup dan kurang khususnya pada poin pertanyaan no 13 s.d 20 pada metode mencegah kerumunan dan mengurangi mobilitas menjadi berpengetahuan baik. Sehingga kita akan mampu membantu tujuan utama pemerintah untuk mengatasi penyebaran Covid 19 ini khususnya di kalangan komunitas pendidikan (siswa sekolah).

\section{DAFTAR PUSTAKA}

Anies. (2020). Covid-19: Seluk Beluk Corona Virus Yang Wajib Dibaca (Cetakan 1). Yogyakarta: Arruzz Media.

Buana, D. R. (2020). Analisis Perilaku Masyarakat Indonesia dalam Menghadapi Pandemi Virus Corona (Covid-19) dan Kiat Menjaga Kesejahteraan Jiwa. Jurnal Sosial \& Budaya Syar'i FSH UIN Syarif Hidayatullah Jakarta, 7(3), 217-226. Retrieved from doi:https://doi.org/10.15408/ sjsbs.v7i3. 15082

Cahyadi, R. (2020). Peran Masyarakat Sebagai Ujung Tombak Penanganan Covid-19. Retrieved 
July 27, 2021, from https://kependudukan.lipi.go.id/id/ berit a/seputar-kegiatan-ppk/853peran masyarakat-sebagai-ujungtombak-penanganan-covid-19

Erlyn, F., Putra, I. D., \& Hendra, D. (2020). Peningkatan Pengetahuan Siswa Dalam Pencegahan Penularan Covid-19. JMM (Jurnal Masyarakat Mandiri), 4(4), 663669. Retrieved from https://doi.org/10.31764/jmm.v4i4. 2652

Guan, W. (2020). Clinical characteristics of coronavirus disease 2019 in China. New England Journal of Medicine, 382(18), 1708-1720. Retrieved from doi: 10.1056/NEJMoa2002032

Kemenkes RI. (2020). Pedoman Pencegahan dan Pengendalian Coronavirus Disease (Covid19) Bagi Pemerintah Daerah. Pencegahan, Pengendalian, Diagnosis dan Manajemen. Jakarta: Kementerian Kesehatan Republik Indonesia.

Mona, N. (2020). Konsep Isolasi Dalam Jaringan Sosial Untuk Meminimalisasi efek Kontagius (kasus Penyebaran Virus Corona Di Indonesia). Jurnal Sosial Humaniora Terapan, 2(2), 117125. Retrieved from https://doi.org/10.74.54/jsht.v2i2.8
6

Nidaa, I. (2020). Gambaran Pengetahuan Masyarakat Pekalongan tentang Covid-19. Jurnal Litbang Kota Pekalongan, 19(1), 64-73. Retrieved from https://jurnal.pekalongankota.go.id /index.php/litbang/article/view/128 $/ 125$

Power, K. (2020). The Covid-19 pandemic has increased the care burden of women and families. Sustainability: Science, Practice and Policy, 16(1), 67-73.

Soekanto, S. (2019). Sosiologi Suatu Pengantar (Edisi Baru). Jakarta: Rajawali Press.

Sukesih, Usman, Budi, S., \& Sari, D. N. A. (2020). Pengetahuan Dan Sikap Mahasiswa Kesehatan Tentang Pencegahan Covid-19 Di Indonesia. Jurnal Ilmu Keperawatan Dan Kebidanan, 11(2), 258-264. Retrieved from https://ejr.stikesmuhkudus.ac.id/in dex.php/jikk/article/view/835/0

Syamsudin, A. R., \& Damaianti, V. S. (2018). Metode Penelitian Pendidikan Bahasa (Cetakan 2). Bandung: Remaja Rosdakarya. 